\title{
Extensive human platelet specific antigens typing of blood donors of different geographical origin to manage platelet transfusion in alloimmunized patients: Experience from a transfusion center in Northeastern Italy
}

\author{
Donatella Londero, Mauro Miani, Cristina Rinaldi, \\ Vivianna Totis, Vincenzo de Angelis
}

\begin{abstract}
Aims: As a consequence of global migration flows the risk of HPA alloimmunization may be increased for recipients of platelets from ethnically diverse donors. In this study, the frequencies of HPA in donors of different geographical origin were determined in a Northeastern Italy Transfusion Department. Methods: One hundred and ninety-nine apheresis platelet donors, including Europeans ( $n=154)$ and North Africans $(n=29)$, were enrolled. DNA was extracted with a commercial kit (Bee-Robotic). Extensive HPA genotyping was performed with BloodChip ID HPA (ProgenikaGrifols). Chi-squared test for Hardy-Weinberg equilibrium was used to compare frequencies. Results: The allele a was clearly predominant for HPA 1-11 in both European and North African donors. The allele b was absent for HPA 6-7-810-11 in Europeans and for HPA 4-6-7-8-9-10-11 in North Africans. For HPA-15, allele b was more frequent than allele a in North Africans. One case of HPA-4ab and one case of HPA-9abw were
\end{abstract}

Donatella Londero ${ }^{1}$, Mauro Miani ${ }^{1}$, Cristina Rinaldi ${ }^{1}$, Vivianna Totis ${ }^{1}$, Vincenzo de Angelis ${ }^{1}$

Affiliations: ${ }^{1}$ Immunohematology Laboratory, Department of Transfusion Medicine, Azienda Sanitaria Universitaria Integrata di Udine, Udine, Italy.

Corresponding Author: Dr. Donatella Londero, Immunohematology Laboratory, Department of Transfusion Medicine, Azienda Sanitaria Universitaria Integrata di Udine, Via Pozzuolo 330, 33100 Udine, Italy; Email: donatella.Iondero@ asuiud.sanita.fvg.it

Received: 24 October 2017

Accepted: 21 December 2017

Published: 22 January 2018 detected in Europeans. All HPA genotypes were consistent with Hardy-Weinberg equilibrium. Gene frequencies between both ethnic groups were similar excepting HPA-2 $(p=0.0342)$. Conclusion: In our population, there should not be clinically relevant increased risk of posttransfusion purpura or platelet transfusion refractoriness secondary to antibodies to HPAs for recipients of platelet concentrates from blood donors of European and North African ethnicity.

Keywords: Apheresis-donation, Genotyping, Platelet antigens, Platelet-transfusion

\section{How to cite this article}

Londero D, Miani M, Rinaldi C, Totis V, Angelis VD. Extensive human platelet specific antigens typing of blood donors of different geographical origin to manage platelet transfusion in alloimmunized patients: Experience from a transfusion center in Northeastern Italy. Int $\mathrm{J}$ Blood Transfus Immunohematol 2018;8:4-11.

Article ID: 100036IJBTIDL2018

$$
* * * * * * * * *
$$

doi: 10.5348/ijbti-2018-36-OA-2

\section{INTRODUCTION}

Human platelet specific antigens (HPAs) are immunogenic structures located on the membrane of platelets. Transfusion, pregnancy or transplantation can expose individuals to allogeneic HPAs and elicit 
an immune response. Alloantibodies against HPA are mainly involved in fetal and neonatal alloimmune thrombocytopenia (FNAIT), platelet transfusion refractoriness and, rarely, in post-transfusion purpura [1-4].

Currently, 34 platelet alloantigens have been described [5-8]; their frequency differs between human groups and could affect the risk of alloimmunization. In Caucasians alloantibodies, most commonly implicated in platelet refractoriness and FNAIT are against HPA1, while anti-HPA $2 \mathrm{~b}$ and anti-HPA $4 \mathrm{~b}$ are more prevalent in Japanese population affected by FNAIT and refractoriness, respectively [9-16]. Although the majority of platelet refractoriness (80\% or more) is caused by anti-human leukocyte antigen (HLA) antibodies, the use HLA-matched units is not sufficient to provide better increments in platelet count [17].

In recent years, a rise in platelet transfusion has been observed. Factors that may explain this trend include an increase in the general population, an ageing population, an increase in the incidence and prevalence of hematological malignancies, and changes in the management of hematology-oncology patients [18]. These latter factors account for the majority of platelet transfusion refractoriness [19], which is altogether prevalent among $15-25 \%$ of hematology-oncology patients. Refractoriness has been linked to inferior clinical outcomes, including bleeding and mortality, as well as higher health care costs [19].

To date, our blood donor population in Friuli-Venezia Giulia (FVG) region (Northeastern Italy) consists of Europeans, North Africans, and to a smaller extent, Sub-Saharans and Asians, as a consequence of global migration flows. This population ethnicity profile can be found in many other places of Europe. Differences in the ethnicity of blood donors and transfusion recipients are a key factor in immunization of some multitransfused patients to blood group antigens. Therefore, prospective matching requires the recruitment of donors from the same ethnic group as the patient population. Regarding HPA compatibility, extensive HPA typing of blood donors and the knowledge of HPA frequencies in different human populations are important tools to guide decision-making concerning platelet transfusion.

The aim of this study was to compare the frequency distribution of HPA alleles among ethnically diverse apheresis platelet donors to determine whether an increased HPA alloimmunization risk exists for recipients of platelets from blood donors of other geographical origin, regardless HLA mismatch, and to determine the need to have previously mass-scale genotyped suitable donors available. Currently, no similar study has been yet carried out in Italian blood donors.

\section{MATERIALS AND METHODS}

\section{Study design}

One hundred ninety-nine volunteer platelet apheresis donors belonging to Transfusion Departments of FriuliVenezia Giulia were enrolled in the study between May 2013 and December 2013. Since the study was performed in terms of prevention of alloimmunization management, no refractory patients but only donors were considered for enrolment. The sole inclusion criterion was $\geq 2$ previous platelet apheresis donations in the last two years. Donors were classified by the investigator according to their European, African (North or Sub-Saharan) and Asian geographical origin.

All blood samples were collected after informed consent was given at the act of blood donation. The research was approved by the Hospital Ethics Committee. All procedures were in accordance with the ethical standards of the institutional and/or national research committee and with the 1964 Helsinki declaration and its later amendments or comparable ethical standards.

\section{Procedures}

Peripheral venous blood was collected in ethylenediaminetetraacetic acid (EDTA) tubes and genomic DNA was extracted by using a commercial kit (Bee-Robotic DNA extraction kit, Caernarfon, $\mathrm{UK}$ ), according to the protocol recommended by the manufacturer. The concentration and quality of the DNA obtained were analyzed using a spectrophotometer (Nanodrop, ThermoFisher Scientific, Wilmington DE, USA).

Human platelet specific antigens molecular typing was performed using BloodChip ${ }^{\circledR}$ ID HPA (Progenika Biopharma, a Grifols Company, Derio, Spain) a genotyping assay that uses Luminex $\mathrm{xMAP}^{\circledR}$ technology (Luminex Corporation, Austin, TX, USA) which identifies polymorphisms of 12 Human Platelet Systems (HPA 1-11, 15); the BLOODchip ID Software (BIDS) interprets the quantified signals and produces a file with the genotype results for each of the SNPs included, it also converts the genotypes into predicted phenotypes for the antigens tested. All results were compared with published data [5].

Luminex xMAP technology was validated by comparing results from 96 donor DNA samples analyzed by single specific primer-polymerase chain reaction (SSPPCR) and Luminex xMAP.

\section{Statistics}

Genotype frequencies were estimated by direct counting. A chi-squared test for Hardy-Weinberg equilibrium was calculated to compare the HPA genotype frequencies between our different populations and literature data (IPD-HPA Sequence Database). A p-value less than 0.05 was considered to be statistically significant.

\section{RESULTS}


Table 1 illustrates the human platelet specific antigens allele frequencies among the 199 blood platelet apheresis donors belonging to different donor groups, estimated by direct counting. The average age was of 42 years (range 19-67 years). Since Sub-Saharan African and Asian donor samples were not numerous, only European $(\mathrm{N}=$ 154) and North African samples ( $\mathrm{N}=29)$ were included in statistical analysis. The results of comparison between the observed and expected genotype frequencies are presented in Table 2 for European donors and in Table 3 for North African donors. All tested allele frequencies followed the Hardy-Weinberg equilibrium.

Allele a was clearly predominant for HPA 1-11 in both studied groups and allele b was absent for HPA 6-7-8-10-11 in Europeans and for HPA 4-6-7-8-9-10-11 in North Africans. With regard to HPA-15, allele b was more frequent than allele a in North Africans. One case of HPA-4ab and one case of HPA-9abw were detected in European donors. The presence of the HPA-9abw genotype was confirmed by sequencing (Figure 1).

Regarding comparisons with known populations, our European donors were compared with Italian donors (except for HPA-15 where we used Austrian population) and North African donors were compared with Moroccan people (as $76 \%$ of our donors came from Morocco). No significant difference ( $p$-value $\geq 0.05$ ) was found.

In the comparison using the chi-square test for homogeneity, there was no significant difference between our two studied ethnic groups (p-value $\geq 0.05$ ) except for HPA-2 (p-value $=0.0342)($ Table 4$)$.

During Luminex xMAP technology validation, no sample required repetition because of a failure to reach all internal quality control requirements. Results were concordant in all cases.

Table 1: Human platelet specific antigens allele frequencies in European, African and Asian donors

\begin{tabular}{|c|c|c|c|c|}
\hline \multirow{2}{*}{$\begin{array}{l}\text { HPA allele } \\
\text { frequencies }^{\text {a }}\end{array}$} & \multicolumn{4}{|c|}{ Donors } \\
\hline & $\begin{array}{l}\text { European } \\
(N=154)\end{array}$ & $\begin{array}{l}\text { North African } \\
(\mathbf{N}=\mathbf{2 9})\end{array}$ & $\begin{array}{c}\text { Sub-Saharan African } \\
(\mathbf{N}=7)\end{array}$ & $\begin{array}{c}\text { Asian } \\
(\mathbf{N}=\mathbf{9})\end{array}$ \\
\hline $1 \mathrm{a}$ & 0.847 & 0.862 & 0.857 & 0.944 \\
\hline $1 \mathrm{~b}$ & 0.153 & 0.138 & 0.138 & 0.056 \\
\hline $2 \mathrm{a}$ & 0.945 & 0.845 & 0.929 & 1.000 \\
\hline $2 b$ & 0.055 & 0.155 & 0.071 & 0.000 \\
\hline 3a & 0.620 & 0.672 & 0.500 & 0.722 \\
\hline $3 b$ & 0.380 & 0.448 & 0.500 & 0.278 \\
\hline $4 a$ & 0.997 & 1.000 & 1.000 & 1.000 \\
\hline $4 b$ & 0.003 & 0.000 & 0.000 & 0.000 \\
\hline $5 \mathrm{a}$ & 0.847 & 0.879 & 0.786 & 0.889 \\
\hline $5 b$ & 0.153 & 0.121 & 0.214 & 0.111 \\
\hline $9 a$ & 0.997 & 1.000 & 1.000 & 1.000 \\
\hline $9 b$ & 0.003 & 0.000 & 0.000 & 0.000 \\
\hline $15 \mathrm{a}$ & 0.503 & 0.448 & 0.643 & 0.167 \\
\hline $15 \mathrm{~b}$ & 0.497 & 0.552 & 0.357 & 0.833 \\
\hline
\end{tabular}

HPA: Human Platelet Specific Antigen

${ }^{a}$ Frequencies of HPA alleles $6 \mathrm{a} / 6 \mathrm{~b}, 7 \mathrm{a} / 7 \mathrm{~b}, 8 \mathrm{a} / 8 \mathrm{~b}, 10 \mathrm{a} / 10 \mathrm{~b}$ and $11 \mathrm{a} / 11 \mathrm{~b}$, were $1.000 / 0.000$ in all cases and all donor groups

ITGA2B*2602G,A (HPA9A,9B)

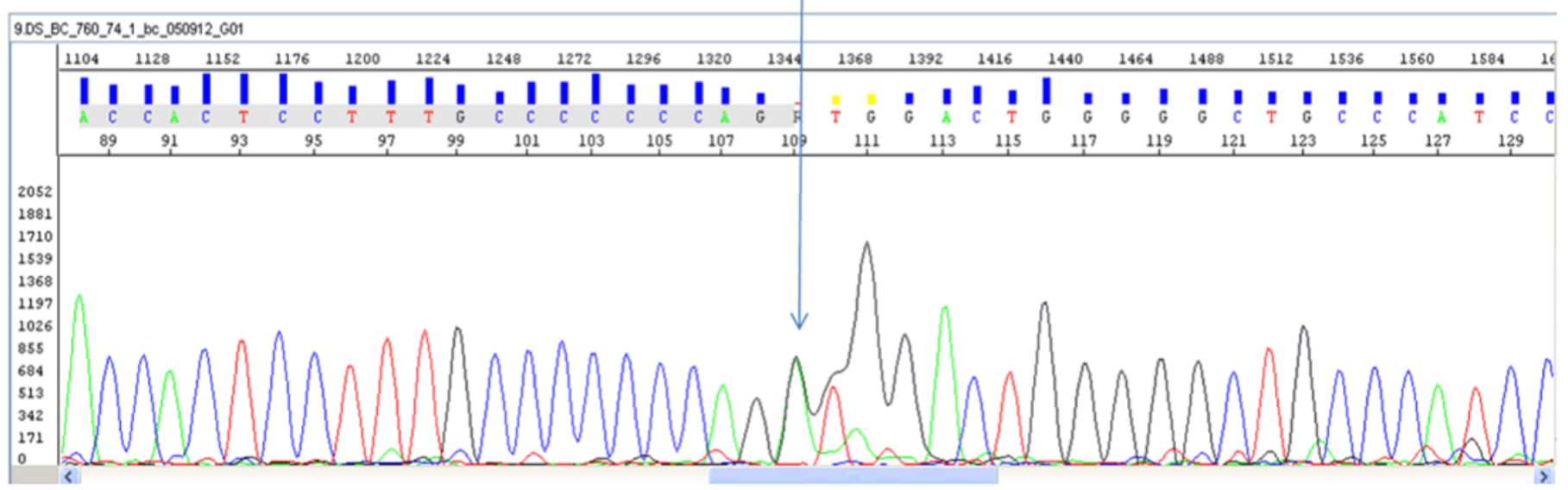

Figure 1: Detail of the sequencing analysis of ITGA2B exon 26 with the nucleotidic heterozygous mutation found at 2602 position (ITGA2B*2602A,G) associated with HPA-9a/b heterozygous genotype. 
Table 2: Hardy-Weinberg analysis of human platelet specific antigens in European donors

\begin{tabular}{|c|c|c|c|c|}
\hline HPA genotype ${ }^{a}$ & Observed frequency & Expected frequency & $\begin{array}{c}\text { Hardy-Weinberg } \\
\text { analysis }\end{array}$ & Gene frequency \\
\hline $1 \mathrm{a} / 1 \mathrm{a}$ & 0.7143 & 0.7181 & \multirow{3}{*}{$\begin{array}{c}\chi^{2}=0.133 \\
\text { p-value }=0.7150\end{array}$} & \multirow{3}{*}{$\begin{array}{l}\text { 1a } 0.847 \\
\text { 1b } 0.153\end{array}$} \\
\hline $1 \mathrm{a} / 1 \mathrm{~b}$ & 0.2662 & 0.2586 & & \\
\hline $1 \mathrm{~b} / 1 \mathrm{~b}$ & 0.0195 & 0.0233 & & \\
\hline $2 a / 2 a$ & 0.8896 & 0.8927 & \multirow{3}{*}{$\begin{array}{c}\chi^{2}=0.526 \\
\text { p-value }=0.4685\end{array}$} & \multirow{3}{*}{$\begin{array}{l}2 \mathrm{a} 0.945 \\
2 \mathrm{~b} 0.055\end{array}$} \\
\hline $2 a / 2 b$ & 0.1104 & 0.1043 & & \\
\hline $2 b / 2 b$ & 0.0000 & 0.0030 & & \\
\hline $3 a / 3 a$ & 0.3831 & 0.3846 & \multirow{3}{*}{$\begin{array}{c}\chi^{2}=0.006 \\
\text { p-value }=0.9394\end{array}$} & \multirow{3}{*}{$\begin{array}{l}\text { 3a } 0.620 \\
\text { 3b } 0.380\end{array}$} \\
\hline $3 a / 3 b$ & 0.4740 & 0.4711 & & \\
\hline $3 \mathrm{~b} / 3 \mathrm{~b}$ & 0.1429 & 0.1443 & & \\
\hline $4 a / 4 a$ & 0.9935 & 0.9935 & \multirow{3}{*}{$\begin{array}{c}\chi^{2}=0.002 \\
\text { p-value }=0.9678\end{array}$} & \multirow{3}{*}{$\begin{array}{l}4 \mathrm{a} 0.997 \\
4 \mathrm{~b} 0.003\end{array}$} \\
\hline $4 a / 4 b$ & 0.0065 & 0.0065 & & \\
\hline $4 b / 4 b$ & 0.0000 & 0.0000 & & \\
\hline $5^{a} / 5^{a}$ & 0.7273 & 0.7181 & \multirow{3}{*}{$\begin{array}{c}\chi^{2}=0.776 \\
\text { p-value }=0.3782\end{array}$} & \multirow{3}{*}{$\begin{array}{l}5 \mathrm{a} 0.847 \\
\text { 5b } 0.153\end{array}$} \\
\hline $5 a / 5 b$ & 0.2403 & 0.2586 & & \\
\hline $5 \mathrm{~b} / 5 \mathrm{~b}$ & 0.0325 & 0.0233 & & \\
\hline $9 a / 9 a$ & 0.9935 & 0.9935 & \multirow{3}{*}{$\begin{array}{c}\chi^{2}=0.002 \\
\text { p-value }=0.9678\end{array}$} & \multirow{3}{*}{$\begin{array}{l}9 \mathrm{a} 0.997 \\
9 \mathrm{~b} 0.003\end{array}$} \\
\hline $9 a / 9 b$ & 0.0065 & 0.0065 & & \\
\hline $9 b / 9 b$ & 0.0000 & 0.0000 & & \\
\hline $15 \mathrm{a} / 1 \mathrm{a}$ & 0.2532 & 0.2533 & \multirow{3}{*}{$\begin{array}{c}\chi^{2}=0.00001 \\
\text { p-value }=0.9996\end{array}$} & \multirow{3}{*}{$\begin{array}{l}15 \mathrm{a} 0.503 \\
15 \mathrm{~b} 0.497\end{array}$} \\
\hline $15 a / 1 b$ & 0.5000 & 0.5000 & & \\
\hline $15 \mathrm{~b} / 1 \mathrm{~b}$ & 0.2468 & 0.2468 & & \\
\hline
\end{tabular}

${ }^{a}$ Frequencies of HPA alleles $6 a / 6 b, 7 a / 7 b, 8 a / 8 b, 10 a / 10 b$ and 11a/11b, were $1.000 / 0.000$ in all cases

Table 3: Hardy-Weinberg analysis of human platelet specific antigens in North African donors

\begin{tabular}{|c|c|c|c|c|}
\hline HPA genotype ${ }^{a}$ & Observed frequency & Expected frequency & $\begin{array}{c}\text { Hardy-Weinberg } \\
\text { analysis }\end{array}$ & Gene frequency \\
\hline $1 \mathrm{a} / 1 \mathrm{a}$ & 0.7241 & 0.7432 & \multirow{3}{*}{$\begin{array}{c}\chi^{2}=0.742 \\
\text { p-value }=0.3889\end{array}$} & \multirow{3}{*}{$\begin{array}{l}\text { 1a } 0.862 \\
\text { 1b } 0.138\end{array}$} \\
\hline $1 \mathrm{a} / 1 \mathrm{~b}$ & 0.2759 & 0.2378 & & \\
\hline $1 \mathrm{~b} / 1 \mathrm{~b}$ & 0.000 & 0.0190 & & \\
\hline $2 a / 2 a$ & 0.6897 & 0.7137 & \multirow{3}{*}{$\begin{array}{c}\chi^{2}=0.978 \\
\text { p-value }=0.3226\end{array}$} & \multirow{3}{*}{$\begin{array}{l}2 \mathrm{a} 0.845 \\
2 \mathrm{~b} 0.155\end{array}$} \\
\hline $2 a / 2 b$ & 0.3103 & 0.2622 & & \\
\hline $2 b / 2 b$ & 0.0000 & 0.0241 & & \\
\hline $3 a / 3 a$ & 0.4828 & 0.4521 & \multirow{3}{*}{$\begin{array}{c}\chi^{2}=0.560 \\
\text { p-value }=0.4541\end{array}$} & \multirow{3}{*}{$\begin{array}{l}\text { 3a } 0.672 \\
\text { 3b } 0.448\end{array}$} \\
\hline $3 a / 3 b$ & 0.3793 & 0.4405 & & \\
\hline $3 \mathrm{~b} / 3 \mathrm{~b}$ & 0.1379 & 0.1073 & & \\
\hline $5 a / 5 a$ & 0.7586 & 0.7732 & \multirow{3}{*}{$\begin{array}{c}\chi^{2}=0.546 \\
\text { p-value }=0.4598\end{array}$} & \multirow{3}{*}{$\begin{array}{l}\text { 5a } 0.879 \\
\text { 5b } 0.121\end{array}$} \\
\hline $5^{a / 5 b}$ & 0.2414 & 0.2122 & & \\
\hline $5 \mathrm{~b} / 5 \mathrm{~b}$ & 0.0000 & 0.0146 & & \\
\hline $15 \mathrm{a} / 1 \mathrm{a}$ & 0.2069 & 0.2010 & \multirow{3}{*}{$\begin{array}{c}\chi^{2}=0.017 \\
\text { p-value }=0.8970\end{array}$} & \multirow{3}{*}{$\begin{array}{l}15 \mathrm{a} 0.448 \\
15 \mathrm{~b} 0.552\end{array}$} \\
\hline $15 \mathrm{a} / 1 \mathrm{~b}$ & 0.4828 & 0.4946 & & \\
\hline $15 \mathrm{~b} / 1 \mathrm{~b}$ & 0.3103 & 0.3044 & & \\
\hline
\end{tabular}

${ }^{a}$ Frequencies of HPA alleles 4a/4b, 6a/6b, 7a/7b, 8a/8b, 9a/9b, 10a/10b and 11a/11b, were 1.00o/0.00o in all cases 
Table 4: Homogeneity test between European population and North African population and literature data

\begin{tabular}{|c|c|c|c|c|c|c|c|}
\hline \multirow{2}{*}{$\begin{array}{l}\text { HPA } \\
\text { allele }\end{array}$} & \multicolumn{3}{|c|}{ Europeans } & \multicolumn{3}{|c|}{ North Africans } & \multirow{2}{*}{$\begin{array}{c}\text { Homogeneity test } \\
\text { European versus } \\
\text { North African } \\
\text { Studied Donors }\end{array}$} \\
\hline & $\begin{array}{l}\text { Studied } \\
\text { Samples }\end{array}$ & $\begin{array}{l}\text { Reference } \\
\text { Population }\end{array}$ & p-value & $\begin{array}{l}\text { Studied } \\
\text { Samples }\end{array}$ & $\begin{array}{l}\text { Reference } \\
\text { Population }\end{array}$ & p-value & \\
\hline $\mathbf{1 a}$ & 0.847 & 0.850 & \multirow[t]{2}{*}{0.9493} & 0.862 & 0.748 & \multirow{2}{*}{0.2729} & \multirow{2}{*}{$\begin{array}{c}\chi^{2}=0.025 \\
\text { p-value }=0.8736\end{array}$} \\
\hline $\mathbf{1 b}$ & 0.153 & 0.150 & & 0.138 & 0.252 & & \\
\hline $\mathbf{2 a}$ & 0.945 & 0.890 & \multirow[t]{2}{*}{0.0806} & 0.845 & 0.818 & \multirow{2}{*}{0.7850} & \multirow{2}{*}{$\begin{array}{c}\chi^{2}=4.487 \\
\text { p-value }=0.0342\end{array}$} \\
\hline $\mathbf{2 b}$ & 0.055 & 0.110 & & 0.155 & 0.182 & & \\
\hline $\mathbf{3 a}$ & 0.620 & 0.610 & \multirow[t]{2}{*}{0.8550} & 0.672 & 0.682 & \multirow{2}{*}{0.9378} & \multirow{2}{*}{$\begin{array}{c}\chi^{2}=0.152 \\
\text { p-value }=0.6963\end{array}$} \\
\hline $\mathbf{3 b}$ & 0.380 & 0.390 & & 0.448 & 0.318 & & \\
\hline $4 a$ & 0.997 & 1.000 & \multirow[t]{2}{*}{0.4791} & 1.000 & 1.000 & \multirow{2}{*}{ NA } & \multirow{2}{*}{$\begin{array}{c}\chi^{2}=0.094 \\
\text { p-value }=0.7586\end{array}$} \\
\hline $4 b$ & 0.003 & 0.000 & & 0.000 & 0.000 & & \\
\hline $5 \mathbf{a}$ & 0.847 & 0.900 & \multirow[t]{2}{*}{0.1647} & 0.879 & 0.861 & \multirow{2}{*}{0.8449} & \multirow{2}{*}{$\begin{array}{c}\chi^{2}=0.198 \\
\text { p-value }=0.6567\end{array}$} \\
\hline $5 \mathbf{b}$ & 0.153 & 0.100 & & 0.121 & 0.139 & & \\
\hline $6 \mathbf{a}$ & 1.000 & 1.000 & \multirow[t]{2}{*}{ NA } & 1.000 & 1.000 & \multirow{2}{*}{ NA } & \multirow{2}{*}{ NA } \\
\hline $6 \mathbf{b}$ & 0.000 & 0.000 & & 0.000 & 0.000 & & \\
\hline $7 \mathbf{a}$ & 1.000 & \multirow[t]{2}{*}{ NA } & \multirow[t]{2}{*}{ NA } & 1.000 & NA & \multirow{2}{*}{ NA } & \multirow{2}{*}{ NA } \\
\hline $7 \mathbf{b}$ & 0.000 & & & 0.000 & & & \\
\hline $\mathbf{8 a}$ & 1.000 & \multirow[t]{2}{*}{ NA } & \multirow[t]{2}{*}{ NA } & 1.000 & NA & \multirow{2}{*}{ NA } & \multirow{2}{*}{ NA } \\
\hline $\mathbf{8 b}$ & 0.000 & & & 0.000 & & & \\
\hline $9 \mathbf{a}$ & 0.997 & \multirow[t]{2}{*}{ NA } & \multirow[t]{2}{*}{ NA } & 1.000 & NA & $\mathrm{NA}$ & $\chi^{2}=0.094$ \\
\hline 9b & 0.003 & & & 0.000 & & & $\mathrm{p}$-value $=0.7586$ \\
\hline $10 a$ & 1.000 & NA & NA & 1.000 & NA & $\mathrm{NA}$ & $\mathrm{NA}$ \\
\hline 1ob & 0.000 & & & 0.000 & & & \\
\hline $11 a$ & 1.000 & NA & NA & 1.000 & NA & NA & NA \\
\hline $\mathbf{1 1 b}$ & 0.000 & & & 0.000 & & & \\
\hline $15 \mathbf{a}$ & 0.503 & 0.500 & 0.9546 & 0.448 & NA & NA & $\chi^{2}=0.295$ \\
\hline $15 b$ & 0.497 & 0.500 & & 0.552 & & & $\mathrm{p}$-value $=0.5870$ \\
\hline
\end{tabular}

$\mathrm{NA}=$ Not applicable

\section{DISCUSSION}

Methods to manage immunological refractoriness include the use of HLA- and/or HPA- matched platelets and platelet cross-matching $[17,20]$, to increase the platelet count. For HPA involving antibodies, genotyping of both donors and recipients is an important tool in the identification of compatible platelets [21, 22]. Therefore, as the start of a recruitment policy, in our study we analyzed the frequency of HPA expression in the FVG Transfusion Medicine Departments blood donors from different geographical origin (European, African and Asian).

The first result from our study is the validation of the Luminex xMAP, an innovative methodology for HPA genotyping which allows the simultaneous typing of 12 antigen systems instead of the six usually evaluated by SSP-PCR; results from DNA sequencing carried out by PCR were always consistent with those from the Luminex
xMAP. This result allowed us to introduce a reliable and affordable genotyping analysis in immunohematology laboratory, thus facilitating the creation of a database for HPA genotyped donors.

When considering the results on HPA genotypes in donors, our preliminary results failed to detect a significant difference in the relative frequency of HPA antigen expression in European and North-African blood donors donating at FVG Blood Transfusion Departments, except for HPA-2 system (Europeans HPA-2a 0.945 HPA-2b 0.055; North-Africans HPA-2a 0.845 HPA-2b 0.155 ; $p$-value $=0.0342$ ), with North-Africans exhibiting somewhat higher frequency of HPA-2b, as recently demonstrated also for Egyptian [23] and Algerian populations [24]. We also observed a predominance of allele a in platelet antigens from HPA-1 to HPA-11 and the absence of allele $b$ for HPA-6,-7,-8,-10,-11 in both ethnicities, as also previously reported by Conti et al. [25]. Moreover, in donors originating from North Africa we noticed the absence of allele $b$ for HPA-4,-9. 
A weak recommendation to transfuse HLA/HPA selected or crossmatch-selected platelet to increase the platelet count in patients with hypoproliferative thrombocytopenia who are refractory to platelet transfusions and have HLA/HPA antibodies has been given in a recent "Guidance on platelet transfusion for patients with hypoproliferative thrombocytopenia" [26]. Different studies show that HLA-selected platelets led to improved transfusion outcomes one hour after transfusion in patients with HLA class I antibodies, although the results at 18 to 24 hours were variable. However, as pointed out in the Guidance, a re-evaluation of the level of evidence of this recommendation should profit from results of studies performed with more recent technologies currently in use for HLA/HPA typing, as the majority of studies on which the recommendation is based were conducted before the year 2000. The importance of affordable and reliable methods for the study of the antigens recognized by alloantibodies to platelets has been recently reviewed [27]. It is clear that limitations of serological systems for detecting antibodies against HPAs can be overwhelmed by genetic technologies such as that employed in this study, which provide powerful tools to identify HPAs and support antibody testing to diagnose alloimmune thrombocytopenia.

Altogether, results of this study suggest that there should not be clinically relevant increased risk of post-transfusion purpura or platelet transfusion refractoriness secondary to HPA antibodies for recipients of platelet concentrates from blood donors of European and North African ethnicity [28]. Although we are aware of the possible bias determined by the difference in the relative magnitude of the population samples, these results seem to exclude the need of creating a pool of platelet donors for those specific ethnicities, as instead required for red cells transfusion to patients on chronic transfusion support where the difference in distribution of some antigenic systems is strongly influenced by the ethnicity [29-31]. However, it is important to remark that preventive matching to avoid HLA/HPA antibody formation is not recommended in any guideline, because of lack of donors and costs.

The opportunity of having a validated mass-scale system for HPA genotyping led us to create a registry of typed donors who provide antigen-negative genotypes that may be useful in different clinical conditions [32].

\section{CONCLUSION}

The 199 HPA-genotyped platelet apheresis donors represent a relevant resource for blood transfusion departments of our region, for a prompt retrieval of matched platelets in patients with HPA correlated alloimmune disorders. Increasing the number of donors from Asia and Africa will also give us the opportunity to obtain a sample of bigger size, allowing for proper statistical analysis and for a contribution to the understanding of the effective value of antigen matched platelet transfusions in HPA alloimmunized patients.

\section{REFERENCES}

1. Kroll H, Kiefel V, Santoso S. Clinical aspects and typing of platelet alloantigens. Vox Sang 1998;74 Suppl 2:345-54.

2. Lucas GF, Pittman SJ, Davies S, Solanki T, Brüggemann K. Post-transfusion purpura (PTP) associated with anti-HPA-1a, anti-HPA-2b and antiHPA-3a antibodies. Transfus Med 1997 Dec;7(4):2959.

3. Peterson JA, McFarland JG, Curtis BR, Aster RH. Neonatal alloimmune thrombocytopenia: Pathogenesis, diagnosis and management. $\mathrm{Br} \mathrm{J}$ Haematol 2013 Apr;161(1):3-14.

4. Vassallo RR. Recognition and management of antibodies to human platelet antigens in platelet transfusion-refractory patients. Immunohematology 2009;25(3):119-24.

5. The Immuno Polymorphism Database, HPA Database (IPD-HPA). 2016.

6. Curtis BR, McFarland JG. Human platelet antigens 2013. Vox Sang 2014 Feb;106(2):93-102.

7. Metcalfe P, Watkins NA, Ouwehand WH, et al. Nomenclature of human platelet antigens. Vox Sang 2003 Oct;85(3):240-5.

8. von dem Borne AE, Décary F. ICSH/ISBT working party on platelet serology: Nomenclature of plateletspecific antigens. Vox Sang 1990;58(2):176.

9. Aster RH. New approaches to an old problem: Refractoriness to platelet transfusions. Transfusion 1988 Mar-Apr;28(2):95-6.

10. Blanchette VS, Rand ML. Platelet disorders in newborn infants: Diagnosis and management. Semin Perinatol 1997 Feb;21(1):53-62.

11. Bussel JB, Zabusky MR, Berkowitz RL, McFarland JG. Fetal alloimmune thrombocytopenia. N Engl J Med 1997 Jul 3;337(1):22-6.

12. Décary F, L'Abbé D, Tremblay L, Chartrand P. The immune response to the HPA-1a antigen: Association with HLA-DRw52a. Transfus Med 1991 Mar;1(1):5562.

13. LangenscheidtF, KiefelV,Santoso S, Mueller-Eckhardt C. Platelet transfusion refractoriness associated with two rare platelet-specific alloantibodies (antiBaka and anti-PlA2) and multiple HLA antibodies. Transfusion 1988 Nov-Dec;28(6):597-600.

14. Matsuhashi M, Tsuno NH, Sone S, et al. The role of alloantibodies against human platelet antigen-15 in multiply platelet transfused patients. Transfusion 2014 Apr;54(4):1093-9.

15. Mueller-Eckhardt C, Kiefel V, Kroll H, MuellerEckhardt G. HLA-DRw6, a new immune response marker for immunization against the platelet alloantigen Bra. Vox Sang 1989;57(1):90-1.

16. Valentin N, Vergracht A, Bignon JD, et al. HLADRw52a is involved in alloimmunization against PLA1 antigen. Hum Immunol 1990 Feb;27(2):73-9.

17. Rioux-Massé B, Cohn C, Lindgren B, Pulkrabek S, McCullough J. Utilization of cross-matched or HLA- 
matched platelets for patients refractory to platelet transfusion. Transfusion 2014 Dec;54(12):3080-7.

18. Estcourt LJ. Why has demand for platelet components increased? A review. Transfus Med 2014 Oct;24(5):260-8.

19. Jia Y, Li W, Liu N, Zhang K, et al. Prevalence of platelet-specific antibodies and efficacy of crossmatchcompatible platelet transfusions in refractory patients. Transfus Med 2014 Dec;24(6):406-10.

20. Vassallo RR, Fung M, Rebulla P, et al. Utility of cross-matched platelet transfusions in patients with hypoproliferative thrombocytopenia: A systematic review. Transfusion 2014 Apr;54(4):1180-91.

21. Shehata N, Denomme GA, Hannach B, Banning N, Freedman J. Mass-scale high-throughput multiplex polymerase chain reaction for human platelet antigen single-nucleotide polymorphisms screening of apheresis platelet donors. Transfusion 2011 Sep;51(9):2028-33.

22. Veldhuisen B, van der Schoot CE, de Haas M. Blood group genotyping: From patient to high-throughput donor screening. Vox Sang 2009 Oct;97(3):198-206.

23. Salem AH, Abdel Hamed AE, Abdalla EM, Almawi W. Gene frequencies of human platelet alloantigens 1-5 in two Arab populations. Blood Transfus 2014 Jan;12 Suppl 1:s281-5.

24. Brouk H, Halle L, Bertrand G, Neche FZ, Ouelaa H, Kaplan C. Human platelet antigen allele frequencies in different Algerian populations. Tissue Antigens 2010 Jun;75(6):673-8.

25. Conti F, Bertrand G, Dezan M, et al. Molecular HPA genotyping by microarray in Brazilian blood donors. Transfusion 2014 Feb;54(2):405-11.

26. Nahirniak S, Slichter SJ, Tanael S, et al. Guidance on platelet transfusion for patients with hypoproliferative thrombocytopenia. Transfus Med Rev 2015 Jan;29(1):3-13.

27. Hayashi T, Hirayama F. Advances in alloimmune thrombocytopenia: Perspectives on current concepts of human platelet antigens, antibody detection strategies, and genotyping. Blood Transfus 2015 Jul;13(3):380-90.

28. Xia WJ, Ye X, Tian LW, et al. Establishment of platelet donor registry improves the treatment of platelet transfusion refractoriness in Guangzhou region of China. Transfus Med 2010 Aug 1;20(4):269-74.

29. Guelsin GA, Rodrigues C, Visentainer JE, et al. Molecular matching for $\mathrm{Rh}$ and $\mathrm{K}$ reduces red blood cell alloimmunisation in patients with myelodysplastic syndrome. Blood Transfus 2015 Jan;13(1):53-8.

30. O’Suoji C, Liem RI, Mack AK, Kingsberry P, Ramsey G, Thompson AA. Alloimmunization in sickle cell anemia in the era of extended red cell typing. Pediatr Blood Cancer 2013 Sep;6o(9):1487-91.

31. Castro O, Sandler SG, Houston-Yu P, Rana S. Predicting the effect of transfusing only phenotypematched RBCs to patients with sickle cell disease: theoretical and practical implications. Transfusion 2002 Jun;42(6):684-90.

32. Hauck-Dlimi B, Hammon K, Eckstein R, et al. Human platelet antigen genotypes in Turkish and Caucasian blood donors in Germany. Tissue Antigens 2012 Sep;80(3):214-8.

\section{Acknowledgements}

We acknowledge Dr. Alessandro Moro for revising the statistical analysis. Dr. Jordi Bozzo (Grifols) is acknowledged for expert review of the text and editorial assistance in the preparation of the manuscript.

\section{Author Contributions}

Donatella Londero - Substantial contributions to conception and design, Acquisition of data, Analysis and interpretation of data, Drafting the article, Revising it critically for important intellectual content, Final approval of the version to be published

Mauro Miani - Substantial contributions to conception and design, Acquisition of data, Analysis and interpretation of data, Drafting the article, Revising it critically for important intellectual content, Final approval of the version to be published

Cristina Rinaldi - Substantial contributions to conception and design, Acquisition of data, Analysis and interpretation of data, Drafting the article, Revising it critically for important intellectual content, Final approval of the version to be published

Vivianna Totis - Substantial contributions to conception and design, Acquisition of data, Analysis and interpretation of data, Drafting the article, Revising it critically for important intellectual content, Final approval of the version to be published

Vincenzo de Angelis - Substantial contributions to conception and design, Acquisition of data, Analysis and interpretation of data, Drafting the article, Revising it critically for important intellectual content, Final approval of the version to be published

\section{Guarantor of Submission}

The corresponding author is the guarantor of submission.

\section{Source of Support}

None

\section{Conflict of Interest}

Authors declare no conflict of interest.

\section{Copyright}

(C) 2018 Donatella Londero et al. This article is distributed under the terms of Creative Commons Attribution License which permits unrestricted use, distribution and reproduction in any medium provided the original author(s) and original publisher are properly credited. Please see the copyright policy on the journal website for more information. 
Access full text article on other devices

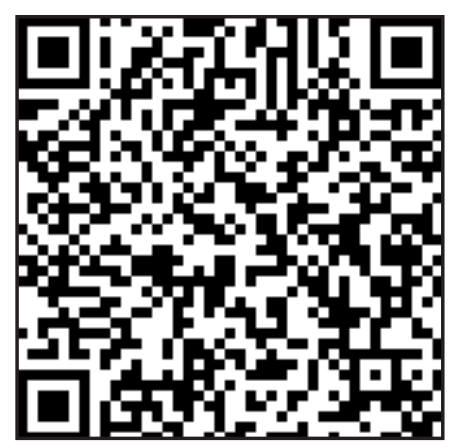

Access PDF of article on other devices

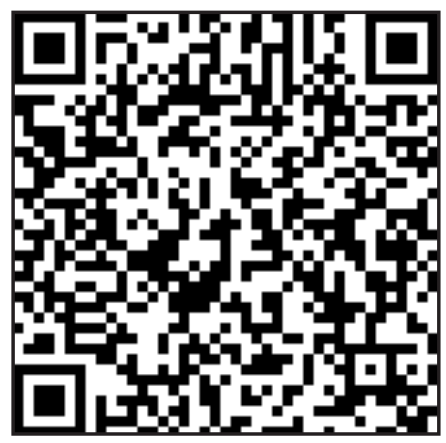

